\title{
Economic Sustainability in Relation to Demographic Decline of Celtic Agglomerations in Central Europe: Multiple-Scenario Approach
}

\author{
Kamila Olševičová \\ University of Hradec Králové, \\ Rokitanského 62, 50003, Hradec Králové \\ Czech Republic \\ Email: kamila.olsevicova@uhk.cz
}

\author{
Alžběta Danielisová \\ Institute of Archaeology of Academy of \\ Sciences of the Czech Republic, \\ Letenská 4, 11801, Prague 1, \\ Czech Republic \\ Email: danielisova@arup.cas.cz
}

\begin{abstract}
Our research attempts to discuss the applicability of social simulation as a tool for exploration the late Iron Age society in both the fortified agglomerations known as the oppida and open settlements within their surroundings, especially from the point of view of the population change and related sustainability of economic production. This paper presents a model of the resilience of the food production system under the dynamically changing (increasing and/or decreasing) population. The models represent a multiple-scenario approach: the scenarios describe different aspects of the oppida occupation (population dynamics in terms of its increase or decrease, food production strategies, landscape changes or economic interactions between oppida and their hinterlands). Within a modelling process different methods are integrated: (1) cellular automata (for the representation of landscape and its changes), (2) system dynamics (population dynamics, economic strategies and ecological and societal rules), and (3) the agentbased component (livestock management).
\end{abstract}

\section{INTRODUCTION}

$\mathrm{O}$ a transition from middle to late Iron Age period we encounter a transformation of the central European society which was represented especially by the new settlement forms - the oppida. They appeared as a part of an economically advanced environment, together with a distinctive intensification of settlement patterns. When they emerged, being understood as "deliberate foundations rather than a gradual evolution", they represented complex systems with multiple functions. However, no issue is as complex and variable at the same time as the oppida and range of their activities, functions and social hierarchies (for the discussion on some of them, see [1]. The central European sites share the dynamics of their occupation: according to the archaeological record the population density increased from the beginning of the occupation (half of the $2^{\text {nd }}$ century $\mathrm{BC}$ ), peaked around the end of the $2^{\text {nd }}$ century / begin-

The support of the Czech Science Foundation under Grant P405/12/0926 "Social modelling as a tool for understanding Celtic society and cultural changes at the end of the Iron Age" is kindly acknowledged. ning of the $1^{\text {st }}$ century $\mathrm{BC}$, and then, within two generations or so, it decreased again. This decrease seems to have been quite rapid and the final population might have been even five times smaller than during its highest density. This probably massive change in the first half of the $1^{\text {st }}$ century $\mathrm{BC}$ was not restricted to the oppida only, but reflected also on the settlements in the countryside even in wider European context [2]. Causes for gradual trend of depopulation can be seen in several factors both endogenous and exogenous: political factors (e.g. massive emigration in reaction to the military events), economic / commercial factors (e.g. difficulties on long distance commercial routes), organizational factors (e.g. insufficient workforce to perform necessary tasks caused by previous famine or plague) or ecological / subsistence problems. However, their analysis is obstructed by the overall lack of detailed archaeological data. In this situation building of explanatory models is the only valid way of exploring the complexity of past societies.

This paper presents a method to ascertain the resilience of the food production system (i.e. the carrying capacity) of the oppida under the dynamically changing (increasing/decreasing) population. The model integrates multiple parts with different methodology: the cellular automata and system dynamics components are used to explore and test various general theoretical hypotheses related to the functioning of the settlements within a particular landscape environment and the ecological and economic rules that are shaping them, the agent-based component enables enhancing the model with individuals (agents) having variety of behavioural patterns (e.g. households living in a particular environment). The models are based on domain knowledge and general palaeodemographic patterns of birth-rates, mortality and migration. We intend to demonstrate the ability to move from a static data set (archaeological and environmental records) to dynamic modelling that incorporates feedback mechanisms, system integration, and nonlinear responses to a wide range of input data. We developed the population dynamics model and the subsequent food production model. The simulation of synthetic population (size, 
structure and subsistence needs) is accompanied by the model of agricultural practices with the aim of investigating the sustainability of the long-term means of production and means of subsistence. Results obtained with the simulation demonstrate limits of the sustainable economy practiced by a constantly growing population under particular environmental and societal settings. This approach can help to analyse past socio-economic processes, determine possible crisis factors and understand ecological and cultural changes. The immediate or gradual impact of the success rate in the food production and its potential influences on the economic and social processes are also addressed.

\section{Late Iron Age and its Economics}

The economy could be explained partially as a response to environmental conditions and climate; economic development then can be seen as an adaptive system to the balance of the ecological factor. However, neither the economy nor society is determined solely by the limits of the environment [3]; social and political factors also played an indispensable role. Therefore, an analysis of the subsistence strategies during the late Iron Age is as much a social and political study as it is an economic one. As such it can eventually help to understand the dynamics of the development in the second half of the $1^{\text {st }}$ century $\mathrm{BC}$ and explain the "collapse" of the complex system represented by the oppida and their hinterlands.

The whole Iron Age world despite its technological innovations, specialization and economic contacts, or its level of complexity, was still principally a world of the common farmer. The organization of food production and its redistribution is an essential factor for understanding the complexity of the society and for determining its limits. Every type of society has a characteristic way of the flow of resources and commodities through it, and the organization of transforming these resources to products [4]. The major aspect in the food production is the significance of agriculture as the primary source of subsistence and organization of potential surplus production. For the socio-economic development, the key aspect is the principle of redistribution of surplus between the consumption and investment. In terms of the technological and economic progress, which contributes to social complexity, the surplus needs not be spent, but accumulated for further investment. When a certain level of complexity within a society is achieved, and seasonal tasks somewhere allow engaging in non-agricultural activities and at the same time a regular supply of necessary foodstuffs from elsewhere is provided, regional differences (in terms of specialization) occur [5]. Such aspects and their mechanisms in the Iron Age are still being discussed. A traditional argument in these discussions concerning the level of complexity in the late La Tène society is that the central places were set in their environments as so called "total consumers" (e.g. [6]). That generally means that they were too "specialised" and hence engaged in other activities, so they were not capable of producing any foodstuffs. This fact should have eventually contributed decisively to the "collapse" of the La Tène society in the $1^{\text {st }}$ century BC. Some of these settlements surely had to overcome or accept some environmental constrains (imposed for example by higher altitude) or were forced to adapt their subsistence practices (e.g. develop an alternative approach to the exploitation of land). There are several proofs providing support to the notion that the food production was an inseparable part of the oppidum's life. The evidence is in fact abundant: numerous livestock, agricultural tools, storage facilities, archaeobotanical and pollen analyses etc. ([7] in print).

In the models of social complexity population dynamics and (over-)exploitation of natural resources play an important role from which wide range of social phenomena have been explained [8]. According to historic sources, exceeding the appropriate carrying capacity was not a rare occasion in history (cf. [9]) even in societies with developed market networks. Intensification of the production led to innovations in the agriculture on one hand but also to a more rapid depletion of the land resources especially where their extent was limited on the other. This prompted behaviour, which could have led to more profound social change at the end of the Iron Age in central Europe.

Our case study location is the oppidum of Staré Hradisko in Bohemia. The model is focused on the oppidum's own agricultural production, i.e. a society pursuing agro-pastoral activities within the given temporal and spatial scale which is tested against subsistence, surplus production and carrying capacity factors. We aim to explore the dynamics of the food production and isolate possible crisis factors imposed either by environment or by unsustainability of the economic strategies pursued. The modelling questions being asked include:

1. Using what cultivation strategies can the population most effectively exploit natural resources in order to be self-sufficient?

2. What are the dynamics of production with constantly growing or declining population (subsistence-surplus - success rate-diminishing returns)?

3. What is the maximum population that can be sustained in a given environment and when is this maximum reached?

\section{SCEnARIOS AND MODELS}

When thinking about the computational models of the Iron Age society and landscape, either we can start with the population data and explore the predicted site catchment, or we can use the landscape data and estimate the likely population in the given area. Our basic idea is to develop the population dynamics model firstly.

NetLogo was used for creation of agent-based and cellular-automata models. The agent-based apporoach is applic- 


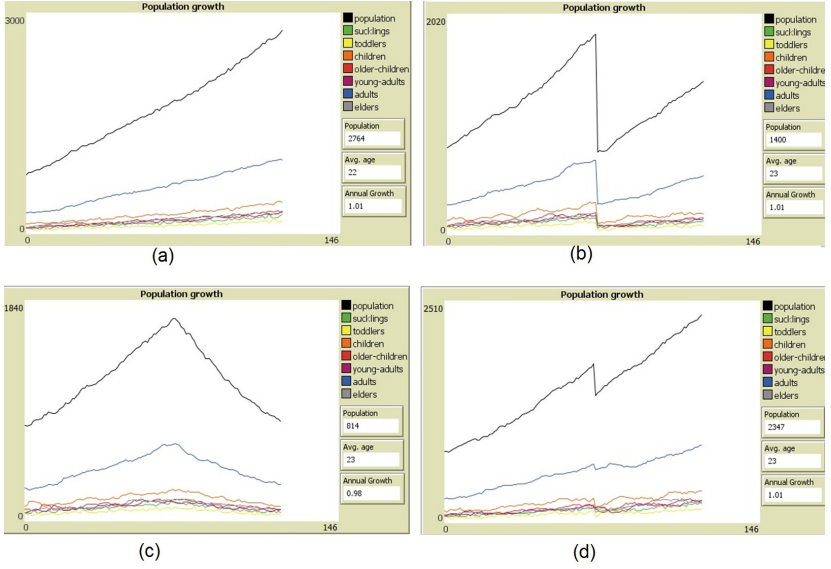

Fig. 1 NetLogo model of population dynamics: (a) baseline, (b) sudden depopulation,(c) gradual depopulation, (d) epidemic

able in case the individuals can be identified (inhabitants of the oppida in our case), cellular automata approach is suitable for land use modelling using GIS data (land allocation in our case). System dynamics modelling software Stella was applied for implementation of the aggregate models where system of stocks and flow capture both the changes of the population structure and the food production.

\section{A. Population Growth and Decline}

The population dynamics model generates the synthetic population of the settlement, including optional population decline and structural changes. Different depopulation scenarios have different reasons and consequences. Synthetic population corresponds to assumptions based on archaeological evidence.

The population dynamics is defined by the initial population, its growth rate and death rate. In our case of the oppidum Stare Hradisko in Bohemia, the initial population is estimated to be between 600-800 individuals. For establishing the appropriate birth rates and life expectancy during the Iron Age the regional model life-tables created by Coale and Demeny for the ancient Roman population [10] are the most relevant source of information about the population dynamics. We used the Model Life Tables Level 3 a 6 West. To complete missing values in the tables (as they were in 5year intervals), the Elandt-Johnson estimation method [11] was applied. The constraints to be satisfied are approximately constant ratios of male/female and ratio of age categories. The model outputs are time series of the synthetic population data (i.e. numbers of individuals and the consumption of the population in calories) representing (1) the energetic requirements of the population, and (2) the availability of the human workforce, i.e. actual number of people in productive age in particular age/sex categories (two main categories were distinguished: "strongforce" - males and young males who can perform heavier task such as plough- ing, harvesting with scythes, forest clearance etc. - and "weakforce" - females, older children and elderly, who can pursue other tasks, such as sowing, hoeing, weeding, manuring, milking, various assistance tasks etc.) for the period of 120 years.

In order to reflect the population decline of the oppidum four (de)population scenarios are formulated (see Fig. 1):

1. Sudden proportional decline (sudden depopulation) is a massive one-time depopulation of 30-60 percent of the inhabitants. It is naturally accompanied with the decline of workforce, livestock and food storage. It corresponds to the hypothesis of the emigration of the part of the population in the $1^{\text {st }}$ half of the $1^{\text {st }}$ century BC.

2. Sudden non-proportional decline (epidemic) is a massive one-time depopulation of 30-60 percent of inhabitants, more conspicuous in certain age groups (suckling, toddlers, children, elderly). It causes significant workforce decline during the following decades.

3. Continuous proportional decline (gradual depopulation) is less extensive but continuous depopulation of 3 percent of the oppidum's inhabitants per year. It corresponds to the hypothesis of continuous emigration beginning in the $1^{\text {st }}$ half of the $1^{\text {st }}$ century BC.

4. For comparison, normal growth of the population (baseline) is defined. In this case the population grows by 2 percent annual increment (cf. [12]) up to 2500-3000 individuals. This scenario corresponds to the stable situation without any adverse events.

The increasing population trend should be reflected in models of food and fodder production (i.e. the spatial change in the field, pasture, and forest area) as well as in the numbers of livestock. The population dynamics model was implemented in NetLogo (see Fig. 1 for outputs) and reimplemented in system dynamics in order to test the model logic.

\section{B. Food Production and Agricultural Practices}

The purpose of this model is to compare agricultural strategies likely to be employed by the oppidum's population in relation to the necessary land-use area and ratio of the population engaged in agricultural work. The food production model applies population modelling outputs (i.e. time-series of synthetic population and its consumption based on caloric tables) together with authentic archaeological and environmental records of the region. The model represents the oppidum located in a gridded landscape (modelled using GIS). The individual cells are allocated topographical (slope, wetness, hydrology), landuse suitability (vegetation, soil productivity), and economic (distance from settlements, distance from water sources) variables. 


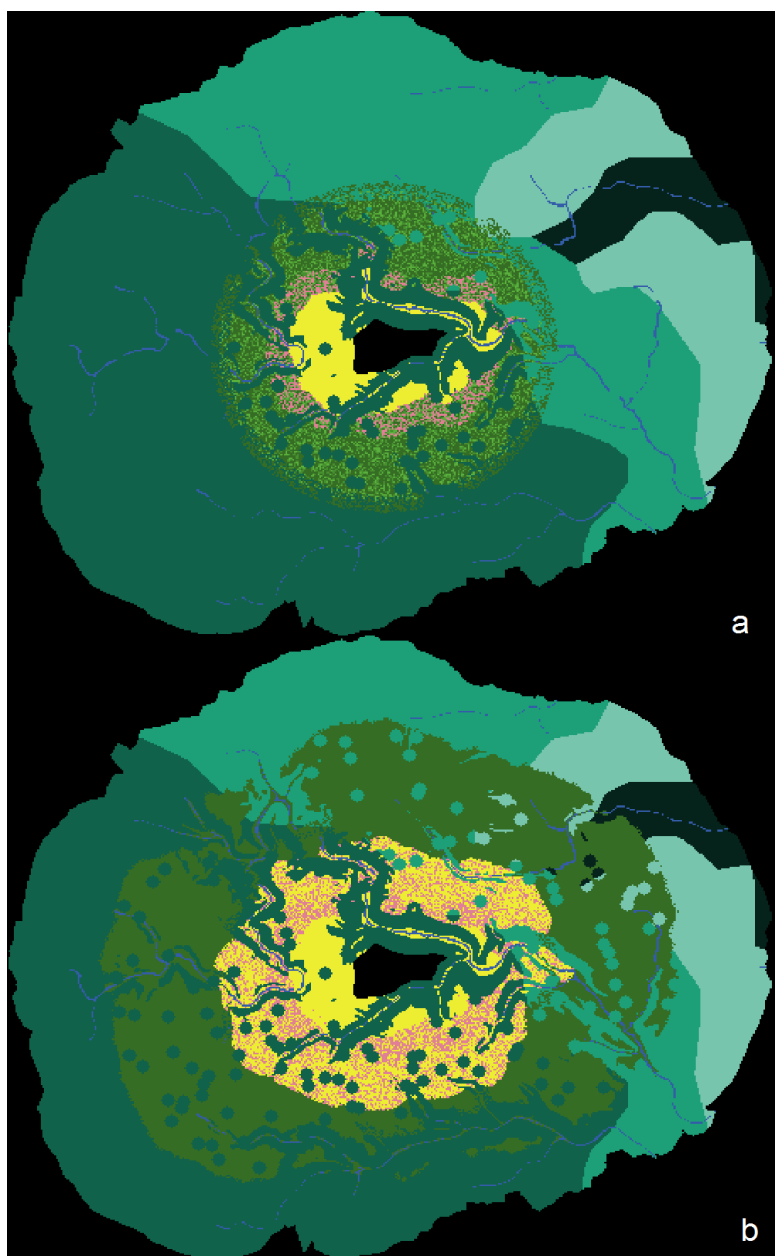

Fig. 2 NetLogo food production model: landscape around the oppidum, cereals and pulses; year 1 (a), year 120 (b)

The evidence of agricultural activities carried out by the oppidum inhabitants can be indicated by particular material groups, archaeobotanical and archaeozoological assemblages, and settlement features (especially storage facilities) [7].

The method of Site Catchment Analysis was used for the modelling of the oppidum's hinterland. Site Catchment Analysis approach is based on models of economics and ecological energy expenditure, and provides a framework within which the economic activities of particular site can be related to the resource potential of the surrounding area. We thus needed to delimit the easily accessible area in the site's surroundings, which would have encompassed fields/fallows, pastures, meadows and managed forests. Considering the locational rules of the "least effort models" and the variable topography, the area was modelled as cost distance according to walking speed from the centre - the oppidum. This roughly corresponds to a distance of 4-5 km generally considered as a threshold for the travelling on a daily or semi-daily return.

The criteria for the prediction of fields were related to the environmental variables: topography, soils, and climate.

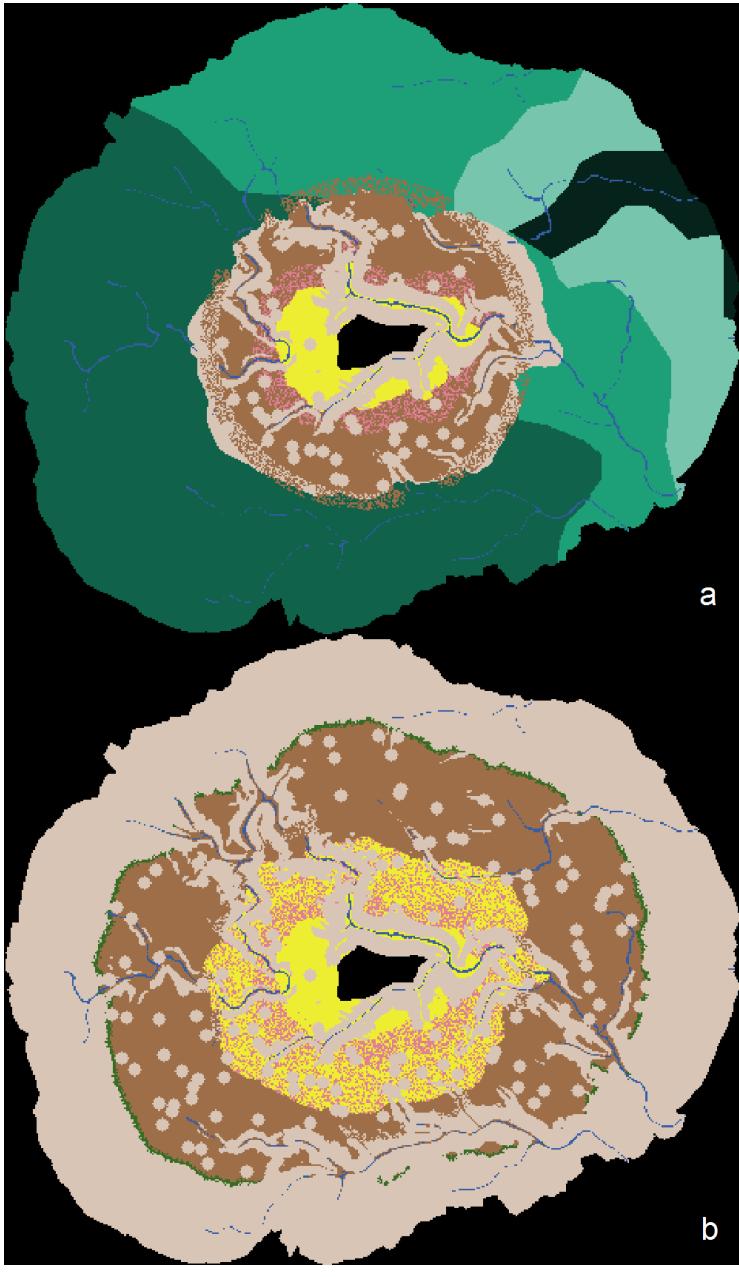

Fig. 3 NetLogo food production model: landscape around the oppidum, fields and fallows, grassland and forest pasture, year 1 (a), year $120(b)$

The fields had to be placed on fairly moderate slopes - less than $5^{\circ}, 5-10^{\circ}$ and $10^{\circ}-15^{\circ}$ respectively. The pastures had to be on slopes less than $30 \%$ and within an accessible distance from the water source. Together with the other variables "soils" (quality, depth, rockiness), "topography", and "wetness" (the topographical tendency of the particular grid cell to be more or less wet) it was put together through the Multi-Criteria Evaluation analysis [13] by which different field suitability categories were created. The plots

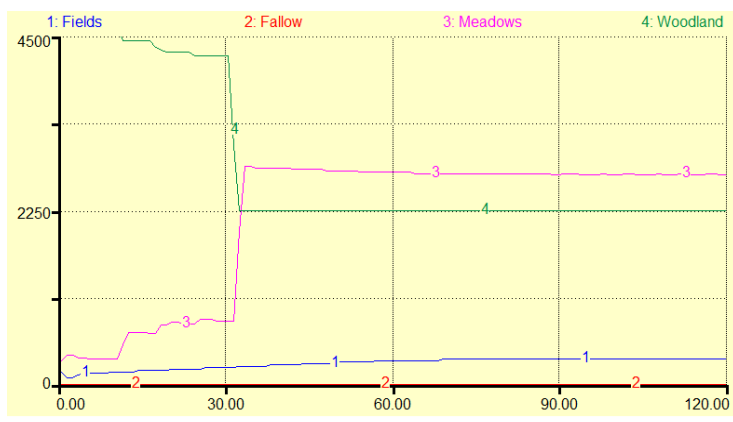

Fig. 4 Stella model of land-use units and their changes during 120 years 


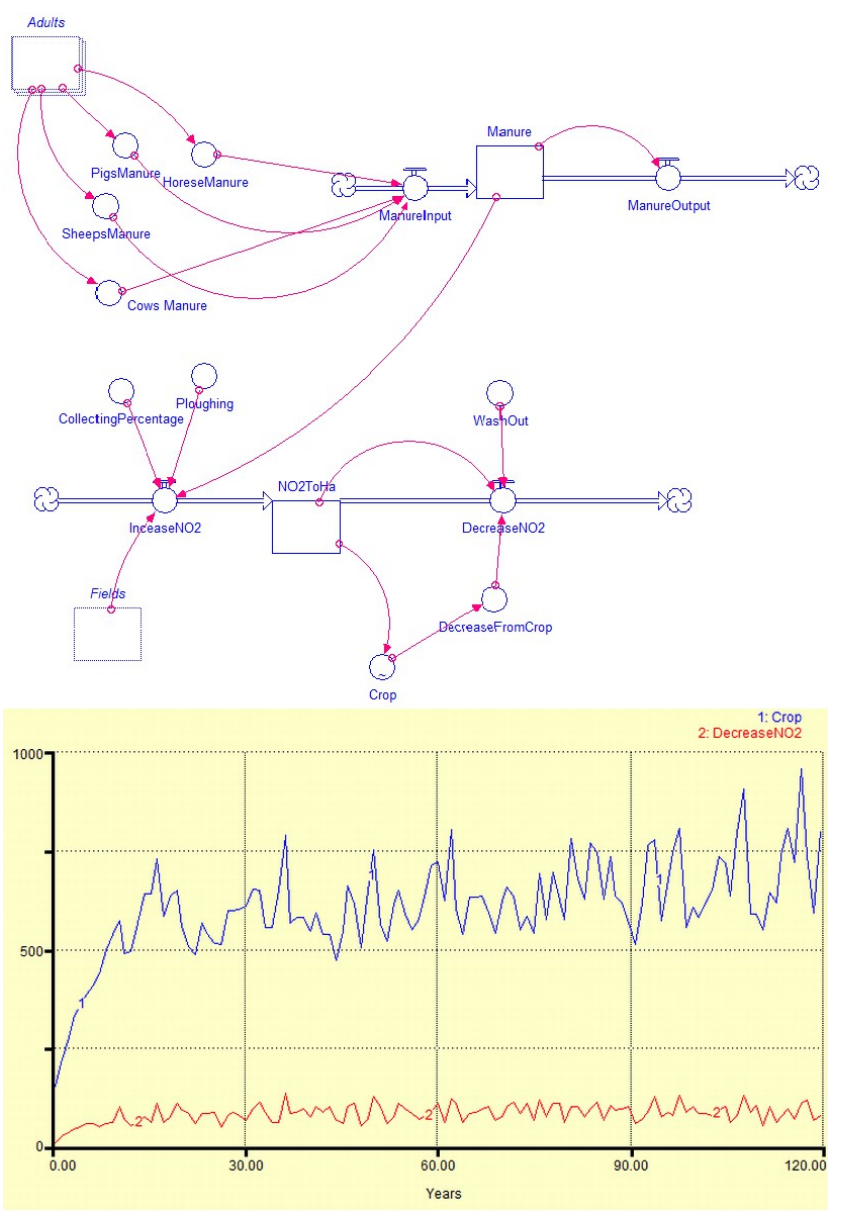

Fig. 5 Stella model of dynamics of nitrogen cycle - diagram in Stella and output

classified as unsuitable (too wet, too rocky or on slopes too steep) were excluded from the field and pasture suitability model. One of the crucial factors for the prediction of both fields and pastures was the accessibility from the settlement. Therefore most suitable areas were plotted as the most

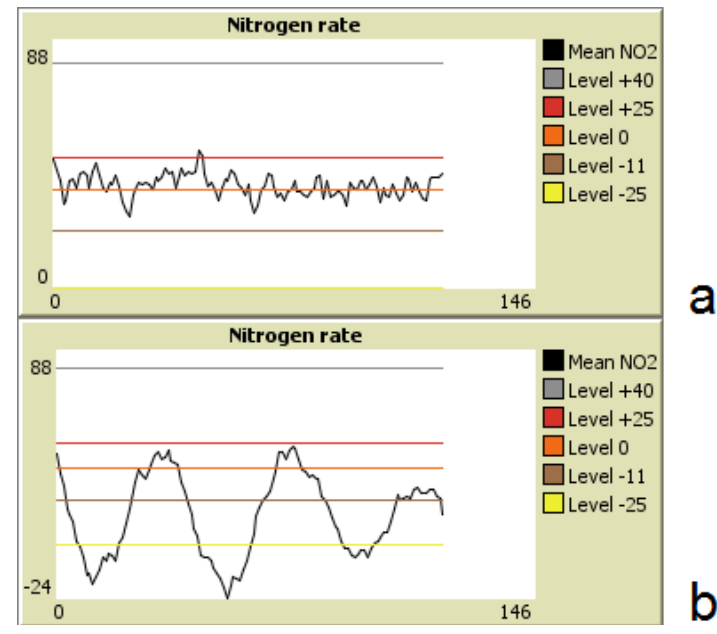

Fig. 6 NetLogo food production model: nitrogen rate for intensive strategy, with normal (a) and gradual (b) manuring fertile zones located as close as possible to the settlement. A cost penalty was included for fields exceeding the distance of $2 \mathrm{~km}$ (cf. [14]). This option applies especially for more intensive regimes of land-use; the cost impact was lower for the fields under the extensive practices. Fields within distance zones could have been subjected to different landuse and management - more intensive closer to the oppidum and more extensive further away in terms of infield and outfield management). The terrains which remained can be attributed to forest pastures, forest openings and woodland.

The default presumption for the model is that each household that cultivated the fields used animal traction. The actual area of fields, as well as the labour input per unit area, varies greatly according to the number of inhabitants and different arable farming strategies employed. With higher yields during an increasing intensity of cultivation, the area of fields could have decreased and vice versa. High annual harvest fluctuations are apparent in modern agricultural experiments (e.g. [15], [16]. [17]). Variable annual yields are also being regularly mentioned in the historic records (cf. [3], [18]). Therefore, using the mean yield estimation in archaeological modelling would provide only a static indication of production. A relative structure of inter-annual fluctuations in the ancient crop yields from a particular area may be established by extrapolating from modern or historical data, preferably from the same region and without estimating any absolute mean value ([16]. [19]). A general range between $500-3000 \mathrm{~kg} / \mathrm{ha}$ (mean value $1500 \mathrm{~kg} / \mathrm{ha}$ for the intensive and $1000 \mathrm{~kg} / \mathrm{ha}$ for the extensive strategy respectively) [7] can be considered as the suitable variance of general yield variability, derived from the information on local environmental and climate conditions, the reconstructed scale and intensity of farming (by "intensity" it is understood the amount of labour input required to process one unit area of land) and production targets (from small subsistence needs to surplus production requirements).

The essential hypothesis supposes the continuous growth of both the population and food production. As precondition, we defined resource levels of the ecosystems (i.e. productivity of the land), productivity potential of the population exploiting these resources (i.e. labour input, technology and task management) and tested if and under what conditions certain resources could become limiting factors, and what implications could be derived from that (e.g. adoption of new subsistence strategies, new technologies, commercial contacts, social transformations, settlement abandonment etc.).

The inputs of the food production model are:

- $\quad$ population data for various scenarios $(1-4)$,

- GIS data for the location of land-use units (maps with specifications of distance from settlement and streams, hydrology, soils, vegetation cover, slope and wetness index),

- diet specification (e.g. the ratio of cereal vs. protein part of the diet), 
- $\quad$ strategy and work allocation settings (e.g. intensive or extensive agricultural strategy, manpower per land unit and per activity).

The following agricultural strategies are assumed to have been possibly practised by the Iron Age population:

1. Intensive farming on small plots: fields were manured namely by stable dung and settlement waste; they were intensively tilled by hand, and weeded. Working animals could be used for ploughing; rotation of crops (cereals, pulses) was practiced. Intensive farming strategy represents the labour demanding option, which tends to be limited in scale or to cover only the subsistence and necessary surplus needs.

2. Extensive farming on large plots: fields included fallows and were managed less intensively. They were manured especially by grazing animals. The plots could be usually under continuous cropping (i.e. no crops rotation) as the periods of fallow allowed for the sufficient regeneration. An extensive strategy could have been employed especially when the available land was abundant, population pressure low, labour was engaged elsewhere, or it was more preferred than the intensive production. With this strategy the potential for surplus production was higher, but could fluctuate heavily.

Both strategies could be combined in terms of infield and outfield land management in order to balance the work/land requirements.

There are different consequences and constraints. Higher cereal consumption requires more intensive growing with ploughing and manuring; intensive manuring requires higher numbers of livestock; more animals require more working hours. Total manpower has to be allocated according to the appropriate sequences of agricultural activities and their timing during the year (seeding, harrowing, ploughing, harvesting or manuring).

Typically, bigger populations have higher consumption requirements, benefit from higher manpower and manage larger areas. If additional land units were required for crop production or livestock grazing, appropriate part of the original woodland has to be cleared and thus changed into the arable land or pastures. The spreading and spatial organization of the site catchment is naturally shaped by accessibility (in model represented by friction surface modelled from local topography). If the limits were achieved, population adapts. Either part of the population leaves, or the food production and/or diet composition has to be changed. The model contains several submodels, reimplemented using system dynamics in order to test the model logic and mathematical operations:

Land-use strategies (Fig. 4.): the model reflects the change of the original, mostly forested landscape into individual land-use categories basing on the population density, number of livestock and agricultural strategy chosen.

Nitrogen cycle: (Fig. 5, 6) - the model aims to test the cycle of nitrogen in soil and its impact on the crop production under both intensive and extensive strategy. With the intensive strategy the nitrogen is applied with farmyard manure from animals stabled per nights and during the winter months. Under the extensive strategy the nitrogen is applied by livestock grazing the fallows and biomass decomposition in the grassland pastures. Two logics were applied in the system dynamics modelling either immediate or gradual releasing of nitrogen affecting the soil fertility for the following harvest (Fig. 6.).

Livestock: the model tests number of livestock in relation to the population density, birth rates and mortality patterns (natural mortality and slaughtering rates in order to maintain the reproducibility of the oppidum's herd) as well as the milk production and fodder requirements. Individual models are created for cattle, horses, pigs and sheep/goats respectively (Fig. 9).

Similarly to the population dynamics model, four scenarios were specified:

1. Sudden event: lost harvest - the crop is damaged either by floods or droughts. The consumption requirements are not covered sufficiently, therefore the population is expected to adapt to the situation.

2. Sudden event: lost animals - it can be caused by disease or theft. The meat and milk calories are not available and/or the ploughing oxen cannot be used, therefore the arable land is affected and the agricultural strategy has to be modified.

3. Sudden event: fire - the crop is destroyed including the storage (reserves from previous one or two years, seed for the next season), the populations is expected to adapt.

4. No event (baseline) - no unexpected events happen, i.e. the food production is not affected by inauspicious weather, fire etc. If the population grows, the food productions grew correspondingly up to the limits of the map.

The food production models apply synthetic populations data (i.e. time-series of number of inhabitants and their consumption based on caloric tables) together with authentic archaeological and environmental records with the region. As precondition, we defined resource levels of the ecosystems (i.e. productivity of the land), productivity potential of the population exploiting these resources (i.e. labour input, technology and task management) and tested if and under what conditions certain resources could become limiting factors, and what implications could be derived from that (e.g. adoption of new subsistence strategies, new technologies, commercial contacts, social transformations, settlement abandonment etc.).

The food production model captures the dynamic of agropastoral economy process (the oppidum's own agricultural production) in recurrent year-to-year cycles which is tested 


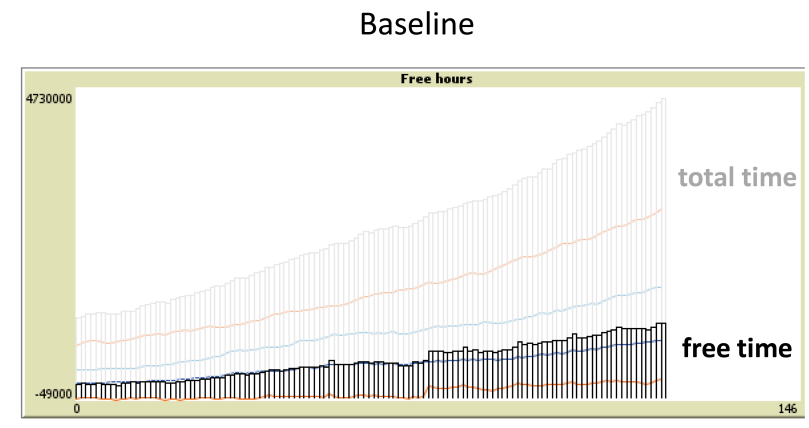

Gradual decline

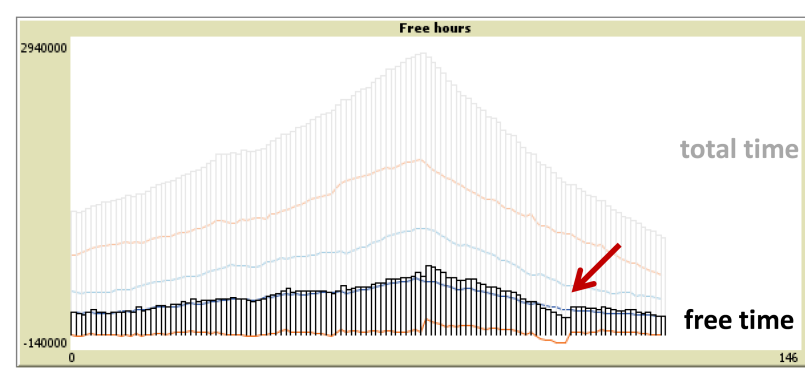

Sudden decline

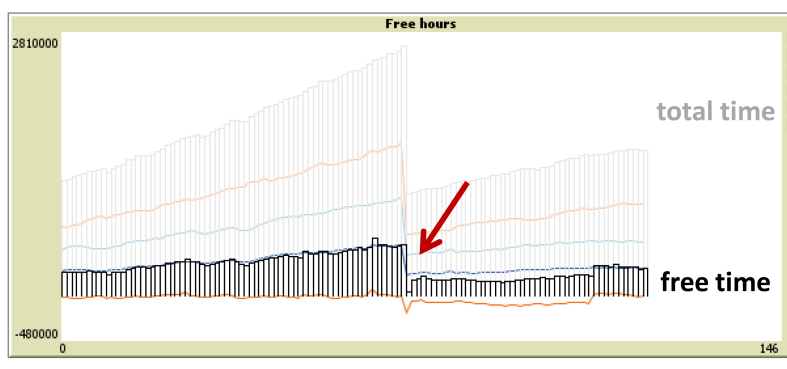

\section{Epidemic}

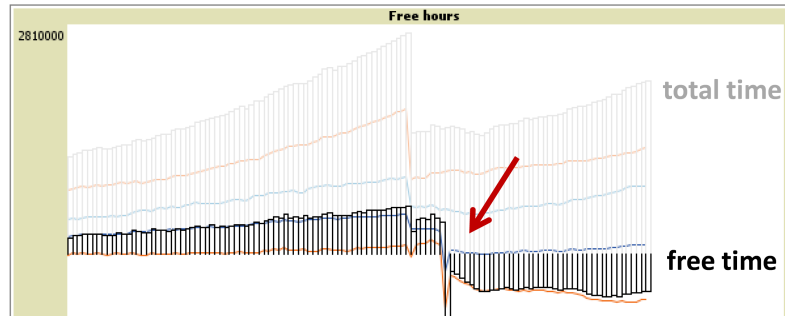

Fig. 7 NetLogo food production model: labour input for depopulation scenarios (female labour includes domestic work, as a default $10 \%$ is allocated to the "non-producers")

against subsistence, surplus production and carrying capacity factors. For each year, certain mixture of main land uses (intensive agriculture, extensive agriculture, grazing livestock and deforestation) is applied. The changes of the food storage make population to adopt to new conditions (to change the mixture of land uses). Results obtained with the simulation demonstrate limits of the sustainable economy practiced by a constantly growing population under particu-
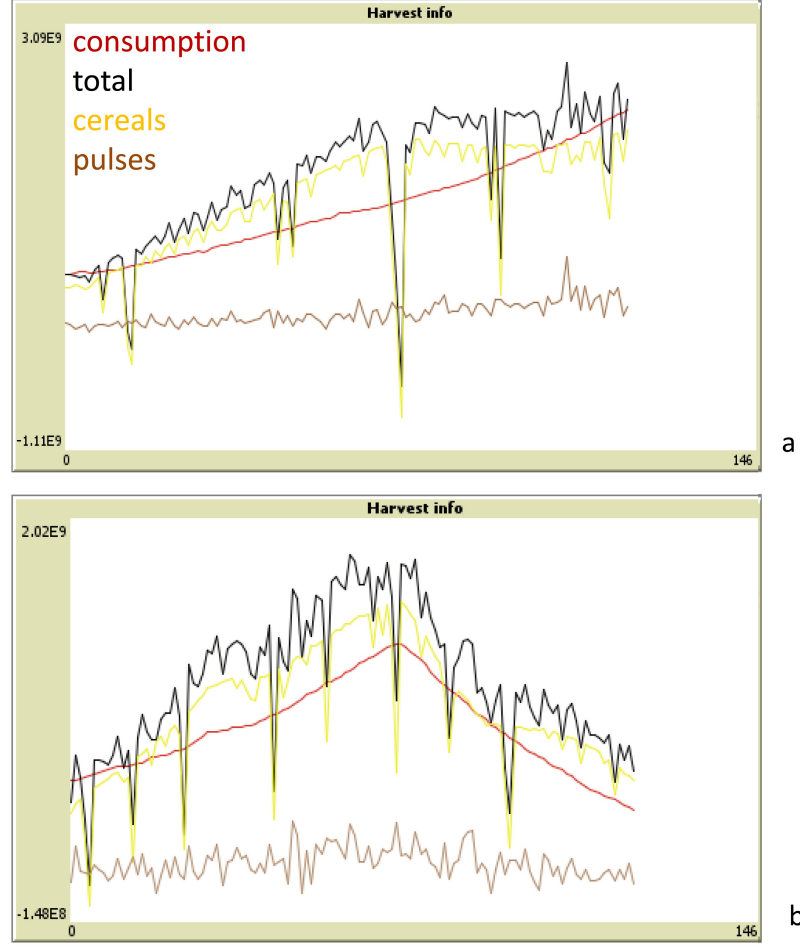

Fig. 8 NetLogo food production model: harvest for baseline (a) and gradual depopulation (b)

lar environmental settings and effect of decreasing population due to emigration and epidemics.

By including the social variables representing farmers' independent decisions to change from one economic strategy into another (or to adopt new ones) in order to cope with worsening conditions of the sustainable agricultural

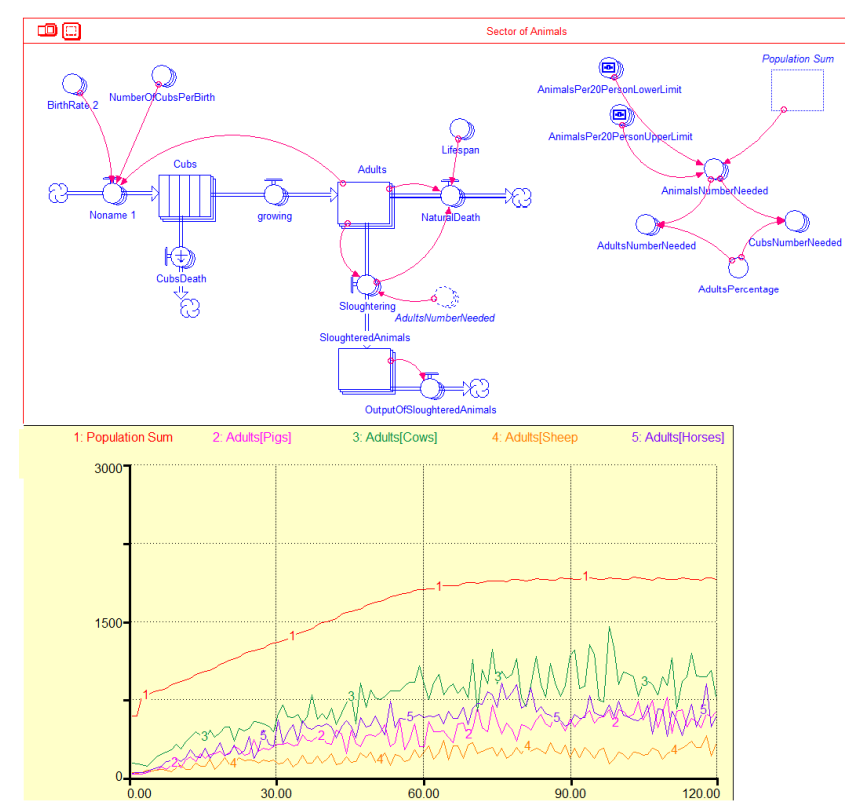

Fig. 9 Stella model of food production: livestock management 


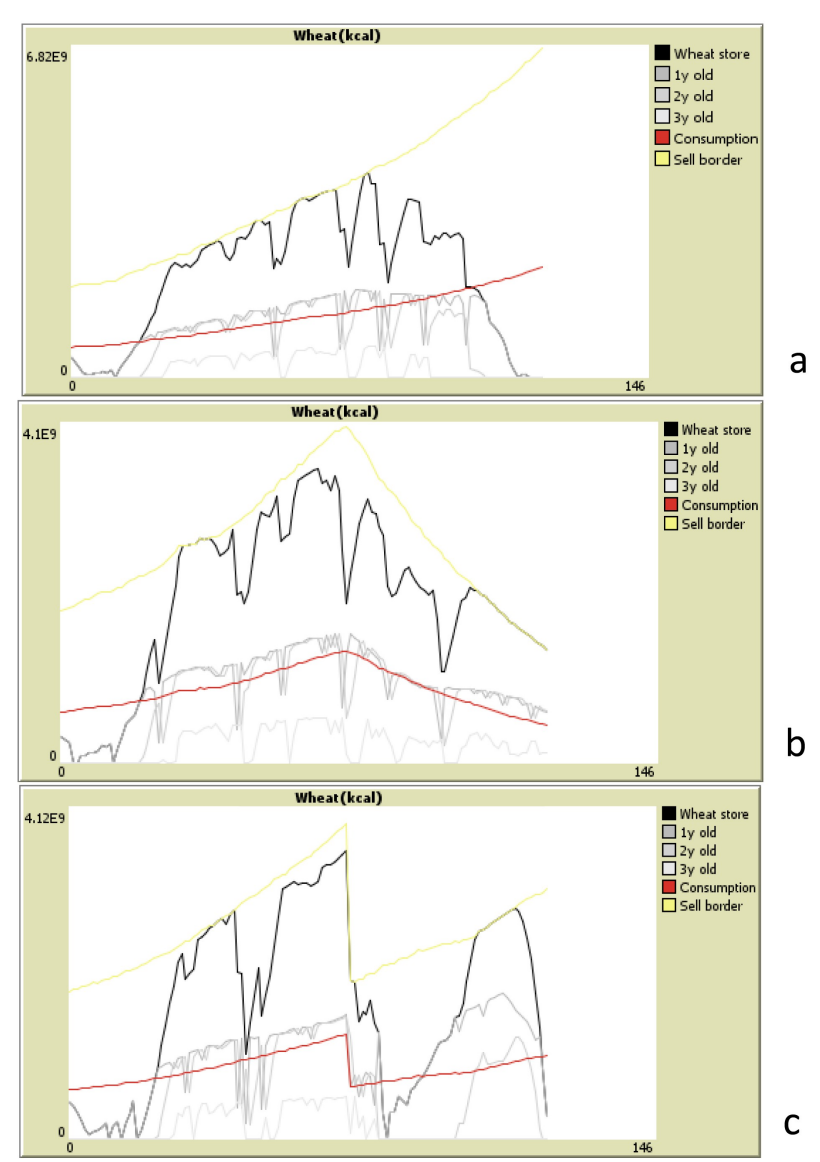

Fig. 10 NetLogo food production model: wheat storage for baseline (a), depopulation (b) and epidemic (c)

practice, the model approaches the complexity of the Celtic society.

\section{RESULTS}

\section{A. Sustainability}

Several major "events" ("destruction of crops", "destruction of storage", "livestock loss") were implemented in order to test the resilience of the agricultural system. Dense aggregated population in a Baseline scenario exhibits problems towards the end of the occupation due partly to the inability to cope with diminished food reserves and partly due to advanced depletion of natural resources. Profound deficit in covering the oppidum's subsistence needs occur which has to be solved by change of agricultural strategy, external food supplies, or emigration. Population decline scenarios and Epidemic scenario on the other hand show that diminished population has higher chances to catch up with the previous sustainable level of production (Fig. 10, 11).

\section{B. Land Use}

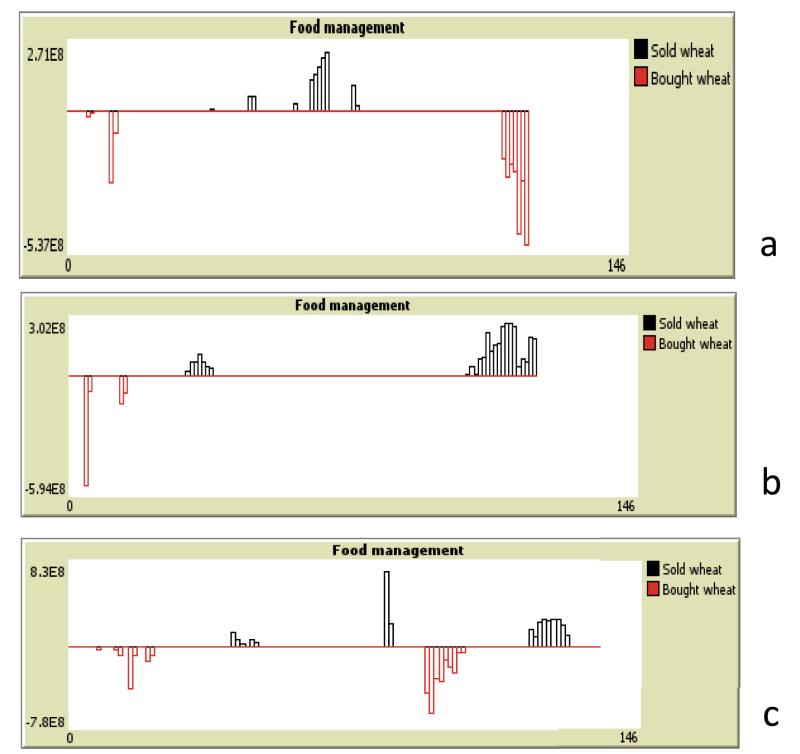

Fig. 11 NetLogo food production model: surplus (black) and deficit (red) for baseline (a), gradual depopulation (b) and epidemic (c)

Depending on the either intensive or extensive strategy chosen, the landscape is covered by the mosaics of fields and pastures gradually verging into the managed forest. With the intensive strategy the livestock has to graze in the forest or, in case of work capacities allocated to forest clearance, on grassland pastures (Fig. 2, 3, 4). With the extensive strategy the livestock is mostly left to graze the fallows. All the population decline scenarios show similar outcome to the landscape - only the infield plots are still managed intensively. Baseline scenario shows clearly the limit of the predicted catchment: by the final years of the simulation the oppidum usually runs out of the area available for pastures. In this case the possible solutions include change of economic strategy, decreasing the number of animals, enlarging the catchment or emigration. The nitrogen cycle submodels capture the influence of manuring (Fig. 5, 6).

\section{Labour Input}

Fig. 7 shows varying human workforce availability under the different scenarios applied. Graphs always show total time (all the working hours available within the oppidum population) and free time (hours beyond the food production tasks available for other activities such as crafts and trade). Within the Baseline scenario the amount of free time increases proportionally to the total time available. Gradual decline scenario copies the declining curve of the total population. While the free time drops within the first generation after the decline it soon catches up to the proportional amount. Both Sudden decline and Epidemic scenarios show difficulties of the oppidum population in coping with diminished working capacities of both people and animals (i.e. ploughing oxen). Epidemic scenario shows delayed impact 
of the disease affecting particular age groups (especially children) at the time.

Available free time amount expresses the opportunity to spend these working hours by different activities nonrelated to the food production that means more room for specialisation in crafts, trade and other social and cultural activities. This parameter thus reflects in a simple way the potential level of complexity of the oppidum's society. The more free time the more the society can be complex and vice versa. Decrease of the free hours means more people are necessary to perform basic food production task and less people were available for other activities much less be the non-producers. Both scenarios of sudden decline and to a certain level also Gradual decline scenario reflect this potential decline of the once complex society.

\section{Discussion And Conclusion}

Results achieved can be discussed in the light of the framework of available data: according to the archaeological record, the settlement density in the late Iron Age in Central Europe increased over some time and then decreased again rapidly. The Population dynamics model provides realistic time series of energetic requirements, workforce availability and age distributions of population of the oppidum's agglomeration. The modelling results showed different outcomes of the economic strategies performed by either growing or declining population.

The limits of the land-use strategies returned from the Baseline scenario, when the population was expected to react by adjusting their economic strategies, started acting around the population density being around 2000-2500 especially due to the depletion of resources (i.e. available field, forest and pasture plots) within the predicted catchment. When experiencing population growth, the households had to work harder in order to keep their life standards, due to the law of diminishing returns ([20] - 1). This concept refers to the fact that while the population increases exponentially, the growth of subsistence resources is only linear and generally slower. As the population approaches the carrying capacity, the production level gradually declines. This means that when reaching the carrying capacity threshold, the surplus becomes zero, and upon further population growth it becomes negative. At this point, the population faces a lack of resources for its reproduction and its density must decline ([20] $-8,10$, Fig. 1.1a) or their subsistence strategies must be adapted to the new situation. Such adaptability processes may include changing the extensive cultivation practices into more intensive land use regimes (i.e. cultivating land with higher labour input on smaller area) or a change in economic preferences to stock farming or craft industries.

What the results show is, since the adequate oppidum population (living from their own resources) was able to exploit environmental resources around the oppidum without simultaneously exhausting them, a rapidly growing number of inhabitants could - at some point - cross the limits of the sustainable agricultural production and experience several stress situations. Especially for the labour intensive scenario, the model resulted in diminishing returns from the cultivated land as the cost of farming more distant field increased. By the population peak, the gradual depletion of stored reserves resulted in a supply crisis, which must have provoked a strong social response. This evolution can be a typical development towards societal decline following the distinctive upsweep accompanied by rapid population growth especially in the environment where the market economy was not an everyday routine ([20], [21]). If the population growth would have reached this maximum value after first $80-90$ years (due to massive immigration for example), that could be the realistic interpretation of the occupation's decline.

However, according to the archaeological record the population started decreasing after 70-80 years (Sudden decline, Gradual decline and Epidemic scenarios). With such a demographic profile, the oppidum's community could in fact practice all land-use strategies without any substantial problems apart from those imposed by natural harvest fluctuations due to weather, accidents (fire, deceasing of the livestock), and other socio-economic (raids, theft) factors.

In our models it has been proven by experiments that not all of the oppidum's population had to be engaged in the agricultural work. There is an archaeological evidence of elite members, which, presumably, were not involved in the agricultural production. Increasing and/or decreasing amount of free time represents in fact the level of society's complexity and its changes reflect decline of this complexity connected to the loss of the production potential. The labour shortage may also point to the necessity of using the external supplies.

\section{Future Directions}

Future studies will build upon the presented models, especially on their share-ability and applicability. The applied approach can be adapted for other regions, other time periods and other economic strategies can be explored.

Our further research is focused on network analysis and network-based modelling of interactions between the oppidum and open village settlements and between individual settlements (i.e. food and raw resources circulation through social contacts). Network analysis (see e.g. [22]) is planned to be used for the interpretation of the data from the sites and for exploration of questions associated with cultural diffusion, settlement hierarchies and regional aspects.

\section{REFERENCES}

[1] Collis, J. (2000) "Celtic" Oppida. In M. H. Hansen (ed.) A comparative Study of Thirty City-State Cultures. An Investigation Conducted by the 
Copenhagen Polis Centre, Historisk-filosofiske Skrifter 21, pp. 229 239. Copenhagen, Det Kongelige Danske Videnskabernes Selskab.

[2] Haselgrove, C. and Guichard, V. (2013) Gaulois sont-ils dans la plaine? Reflections on settlement patterns in Gaul in the 1st century BC. In: S Krausz, A. Colin, K. Gruel, I. Ralston and T. Déchezleprête (eds.) L 'Âge du Fer en Europe. Mélanges offerts à Olivier Buchsenschutz, Collection Mémoires 32, pp. 317-327.

[3] Erdkamp, P. (2005) The grain market in the Roman Empire. A social, political and economic study, Cambridge, Cambridge University Press.

[4] Fuller, D. Q. and J. Stevens (2009) Agriculture and the development of complex societies: An archaeobotanical agenda. In N. Fairbairn and E. Weiss (eds.) From foragers to farmers, Gordon C. Hillman Festschrift, pp. 37 - 57. Oxford, Oxbow Books.

[5] Klír, T. (2010) Die BesiedeJung der Gebirgsgegenden Böhmens im Mittelalter und der frühen Neuzeit - Ausgangspunkte fur eine interdisziplinare Forschung. Archaeologia Historica 35, 373-391.

[6] Salač, V. (2006) Die keltischen Oppida und ihre Macht. In A. KrennLeeb (ed.): Wirtschaft, Macht und Strategie - Höhensiedlungen und ihre Funktionen in der Ur- und Frühgeschichte, pp. 233-245. Archäologie Österreichs Spezial 1

[7] Danielisová, A. and Hajnalová, M. Oppida and agricultural production state of the art and prospects. In S. Hornung (ed.) Produktion Distribution - Ökonomie. Siedlungs- und Wirtschaftmuster der Latènezeit. Kolloquium Otzenhausen 2011. Universitätsforschungen zur prähistorischen Archäologie. Bonn, Habelt (to be published).

[8] Bayliss-Smith, T. (1978) Maximum populations and standard populations: the carrying capacity question. In: Green, D. - Haselgrove, C. - Spriggs, M. (eds.): Social Organisation and Settlement: Contributions from Anthropology, Archaeology and Geography, BAR International Series (Supplementary) 47(i), pp. 129-151.

[9] Schreg, R. (2011) Feeding the village - Reflections on the ecology and resilience of the medieval rural economy. In: J. Klápště, P. Sommer (eds.), Processing, Storage, Distribution of Food. Food in the Medieval Rural Environment, Ruralia VIII, pp. 301-320

[10] Saller, R. (1994) Patriarchy, Property and Death in the Roman Family. Cambridge.

[11] Baili, P. - Micheli, A. - Montanari, A. - Capocaccia, R. (2005) Comparison of Four Methods for Estimating Complete Life Tables from Abridged Life Tables Using Mortality Data Supplied to EUROCARE-3. In: Mathematical Population Studies, 12, pp. 183-198.

[12] Turchin, P. (2009) Long-Term Population Cycles in Human Societies. Annals of the New York Academy of Sciences, vol. 1162 (May), pp. 117.

[13] Eastman, J. R. (2006) IDRISI Andes. Guide to GIS and Image Processing. Worcester, MA.

[14] Chisholm, M. (1979) Rural Settlement and Land Use. An Essay in Location. London.

[15] Rothamsted research (2006) Guide to the Classical and other Long-term Experiments, Datasets and Sample Archive, Bury St. Edmund.

[16] Hejcman, M. - Kunzová, E. (2010) Sustainability of winter wheat production on sandy-loamy Cambisol in the Czech Republic: Results from a long-term fertilizer and crop rotation experiment. Field Crops Research 115, 191-199.

[17] Kunzová, E. - Hejcman, M. 2009: Yield development of winter wheat over 50 years of FYM, N, P and K fertilizer application on black earth soil in the Czech Republic. Field Crops Research 111, 226-234.

[18] Campbell, B. M. S. 2007: Three centuries of English crops yields, 1211 1491, http://www.cropyields.ac.uk

[19] Halstead, P. - O'Shea, J. (eds.) (1989) Bad year economic, Cambridge.

[20] Turchin, P. - Nefedov, S.A. (2009) Secular cycles, Priceton-Woodstock.

[21] Chase-Dunn, C. et al. (2007) Cycles of Rise and Fall, Upsweeps and Collapses: Changes in the Scale of Settlements and Polities since the Bronze Age. Conference on Power Transitions. University of Indiana, Bloomington IN USA.

[22] Knappett, C. (2013) Network Analysis in Archaeology: New Approaches to Regional Interaction. Oxford University Press. 